\title{
Soil Fertility Status of Jamuna Paar region of Allahabad District, Uttar Pradesh, India
}

\author{
B.M. Madhu* and Arun A. David
}

Department of Soil Science and Agricultural Chemistry, Sam Higginbottom University of Agriculture, Technology and Sciences [Naini Agricultural institute] (U.P. state Act No. 35 of 2016, as passed by the Uttar Pradesh Legislature) [Formerly-Allahabad Agricultural Institute], Allahabad, 211007 U.P., India

*Corresponding author

\section{A B S T R A C T}

\section{Keywords}

Soil fertility, N, P, $\mathrm{K}, \mathrm{S}$ nutrients, Micronutrient etc.

Article Info

Accepted:

23 October 2017

Available Online:

10 December 2017
Assessment of the soil fertility status in a Jamuna Paar area was carried out for efficient soil management and cropping systems for sustainable yields. Composite soil samples in surface soil and also sub-surface of different horizons from twelve locations were collected from the Jamuna area by considering their physiographic units. Samples were analyzed for available $\mathrm{N}, \mathrm{P}, \mathrm{K}, \mathrm{S}$ and micronutrients such as $\mathrm{Zn}, \mathrm{Cu}, \mathrm{Fe}$ and $\mathrm{Mn}$. The study indicated that the low content of nitrogen phosphorus and sulphur, medium to high in potassium content. Micronutrients such as $\mathrm{Fe}, \mathrm{Cu}, \mathrm{Mn}$ in sufficient amount and $\mathrm{Zn}$ was deficient noticed in this area. In soils were attributed to low application rates of organic material, high temperature and low rate of application of $\mathrm{N}$ fertilizers, especially in the rainfed areas. To build up organic matter and native nitrogen and maintain nutrient balance in the soil, farmers are advised to adopt FYM and $\mathrm{ZnSO}_{4}$ application, crop rotation and intercropping in the rainfed areas, whereas, in irrigated areas, crop rotation along with application of farm yard manure, $\mathrm{ZnSO}_{4}$ can enhance crop production and soil fertility.

\section{Introduction}

The importance of soil fertility and plant nutrition to the health and survival of all life cannot be understated. As human population continue to increase, human disturbance of the earth's ecosystem to produce food and fiber will place greater demand on soils to supply essential nutrients. Therefore, it is critical that we increase our understanding of the chemical, biological and physical properties and relationships in the soil plant atmosphere continuum that control nutrient availability. If we do not improve and/or sustain the productive capacity of our fragile soils, we cannot continue to support the food and fiber demand of our growing population. In India the land resources available for agriculture are shrinking. Our aim of optimizing the utilization of land resource with intensification of agriculture resulted either in the fast depletion of nutrients or occasionally in their accumulation. It is therefore important to monitor the fertility status of soil from time to time with a view to monitor the soil health. Soil is the most valuable natural resource. It is at the heart of terrestrial ecology, but is finite and 
nonrenewable. To meet the challenges of this century, new understandings and new technologies will be needed to protect the environment and at the same time, produce food and biomass to support society (Brady and Weil, 2004). Systematic study of morphology and taxonomy of soils provides information on nature and type of soils, their constraints, potentials, capabilities and their suitability for various uses (Sehgal, 1999).

A necessity is always felt for more soil database to take up various agricultural developmental activities. Keeping this in mind, the present investigation was taken up to study the soil fertility status of Jamuna Paar region of Allahabad District, Uttar Pradesh

\section{Materials and Methods}

The study area is situated in the South-Eastern part of the State Uttar Pradesh, Allahabad. It lies between the parallels of $25^{\circ} 16^{\prime} 46^{\prime \prime}$ to $25^{\circ} 23^{\prime} 59^{\prime \prime}$ north latitudes and $81^{\circ} 44^{\prime} 03^{\prime \prime}$ to $81^{\circ} 56^{\prime} 58^{\prime}$ 'east longitudes. Allahabad district has such tropical climate that the average maximum temperature ranges between $43^{\circ} \mathrm{C}$ $45^{\circ} \mathrm{C}$ which may go as high as $46^{\circ} \mathrm{C}$ during peak summers. The minimum average temperature is $8-9^{\circ} \mathrm{C}$ which may fall as low as $4^{\circ} \mathrm{C}$ during peak winter months (Dec. Jan.) The average rainfall of the district is $960 \mathrm{~mm}$ and the monsoon season is spread between July-September. The area is under 'Ustic' soil moisture regime and 'Hyperthermic' soil temperature regime. Dhak (Buteaman osparma), Kakor (Ziziphus globerrima), Aonla (Emblica oficinalis), Kahwa (Terminalia arjuna), Jharberi (Ziziohus numilaria), Mahua (Madhuca indica), neem (Azadiracta indica) Chiraunji (Buchanania ianzo) Semal (Salmania malabarica), and Bahera (Terminalia belerica) are the predominant trees found in the study area. Soil survey was carried out for using Tehsils map mainly three blocks are selected, within these blocks each block randomly selected four villages. i.e. Chaka (Marauka uparhar- $\mathrm{P}_{1}$, Tigonotha- $\mathrm{P}_{2}$, Semera- $\mathrm{P}_{3}$ and Mohiuddinpur$\mathrm{P}_{4}$ ), Jasra (Semara kalban- $\mathrm{P}_{5}$, Kottvarankapura- $\mathrm{P}_{6}$, Pandar- $\mathrm{P}_{7}$ and Parsara$\mathrm{P}_{8}$ ) and Karchana (Mungori- $\mathrm{P}_{9}$, Bendo- $\mathrm{P}_{10}$, Munglaha- $\mathrm{P}_{11}$ and Galibabhadh- $\mathrm{P}_{12}$ ). This area is henceforth called in this entitled as "Jamuna Paar Region". The location of the Jamuna paar region is shown in Figure 1.

Soil samples were collected from three different blocks each block were studied four pedons horizon-wise soil samples were collected from total twelve pedons. The fertility status of the pedons was studied. Locations of the pedons were recorded with the help of GPS device. Composite soil samples were prepared wherever land features and soil type were similar in a homogenous unit. Soil samples were air dried in shade and powdered gently with a wooden mallet, passed through $2 \mathrm{~mm}$ sieve and analyzed for Nitrogen was determined by alkali extractable nitrogen method (Subbaiah and Ashija, 1956), available P by Olsen et al., (1954), available $\mathrm{K}$ through a flame photometer after extraction with ammonium acetate (Toth and Prince 1949) and Available sulphur was extracted from the soil using 0.15 per cent calcium chloride solution and sulphur was determined by Black (1965). Micronutrients namely Zn, $\mathrm{Cu}, \mathrm{Fe}$ and $\mathrm{Mn}$ were analyzed by DTPA extraction procedure (Lindsay and Norvell, 1978).

\section{Results and Discussion}

The available nitrogen status in the study area ranged from 248.00 to $280.05 \mathrm{~kg} \mathrm{ha}^{-1}$ in surface horizons and from 174.00 to 275.16 $\mathrm{kg} \mathrm{ha}^{-1}$ in sub-surface horizons. In general, soils are low in available nitrogen which could be due to low organic matter content in these soils. Low rainfall and low vegetation were reported to cause faster degradation and 
removal of organic matter leading to nitrogen deficiency (Ashok, 2001). The available phosphorus status in the study area ranged from 15.30 to $20.48 \mathrm{~kg} \mathrm{ha}^{-1}$ in surface horizons and from 7.16 to $18.26 \mathrm{~kg} \mathrm{ha}^{-1}$ in sub-surface horizons. This might be due to variation in soil properties like clay content, CEC and $\mathrm{P}$ fixation capacity.

In addition to this, it was observed that the farmers are using only DAP as the source of nutrients in adequate quantity. Similar results were reported by Patil et al., (2011) and Ravikumar et al., (2009). The available potassium content of soils ranged from low $\left(134.92 \mathrm{~kg} \mathrm{ha}^{-1}\right)$ to high $\left(267.0 \mathrm{~kg} \mathrm{ha}^{-1}\right)$ in surface horizon and from 134.26 to $212.12 \mathrm{~kg}$ $\mathrm{ha}^{-1}$ in sub-surface horizons (Table 1). In general soils which are developed on ravenous area, piedmont plain and alluvial plain, did not show any distribution pattern which could be due to stratification of these soils. The same indefinite pattern was found in soils of Ghaggar river basin as reported by Singh and Ahuja (1990). Soils in the study area in general could be grouped in to medium to high in available $\mathrm{K}$ content.

\section{Available micronutrients}

The available micronutrients content in jamuna paar region soils was medium to high, ranged from $\mathrm{Fe}$ (5.23 to 16.70), $\mathrm{Cu}$ (1.12 to 4.12) and $\mathrm{Mn}$ (3.20 to 15.53$) \mathrm{mg} \mathrm{kg}^{-1}$ (Table 1) in surface horizons. All the soils pedon showed decreasing trend in available $\mathrm{Fe}, \mathrm{Cu}$ and Mn with depth. Rajkumar et al., (1994) reported that the overall higher $\mathrm{Fe}, \mathrm{Cu}$ and Mn content in the study area might be due to the parent material. Soils derived from granite gneiss showed higher copper content. The available $\mathrm{Zn}$ content in jamuna paar region soils was low to medium, ranged from 0.52 to $0.95 \mathrm{mg} \mathrm{kg}^{-1}$ (Table 1) in surface horizon and from 0.12 to $0.88 \mathrm{mg} \mathrm{kg}^{-1}$ in sub-surface horizon. All the soils pedon showed decreasing trend in available $\mathrm{Zn}$ with depth. The larger extent of zinc deficiency was attributed to the alkaline soil condition and richness of $\mathrm{CaCO} 3$ which might have precipitated zinc as hydroxides and carbonates. Many researchers reported reduced solubility and mobility of zinc and thereby decreased availability of zinc under alkaline soil conditions (Vijayshekar et al., 2000; Thangasamy et al., 2005 and Ravikumar et al., 2009).

Plate.1 Google earth map in Jamuna paar region of Allahabad (U. P.)

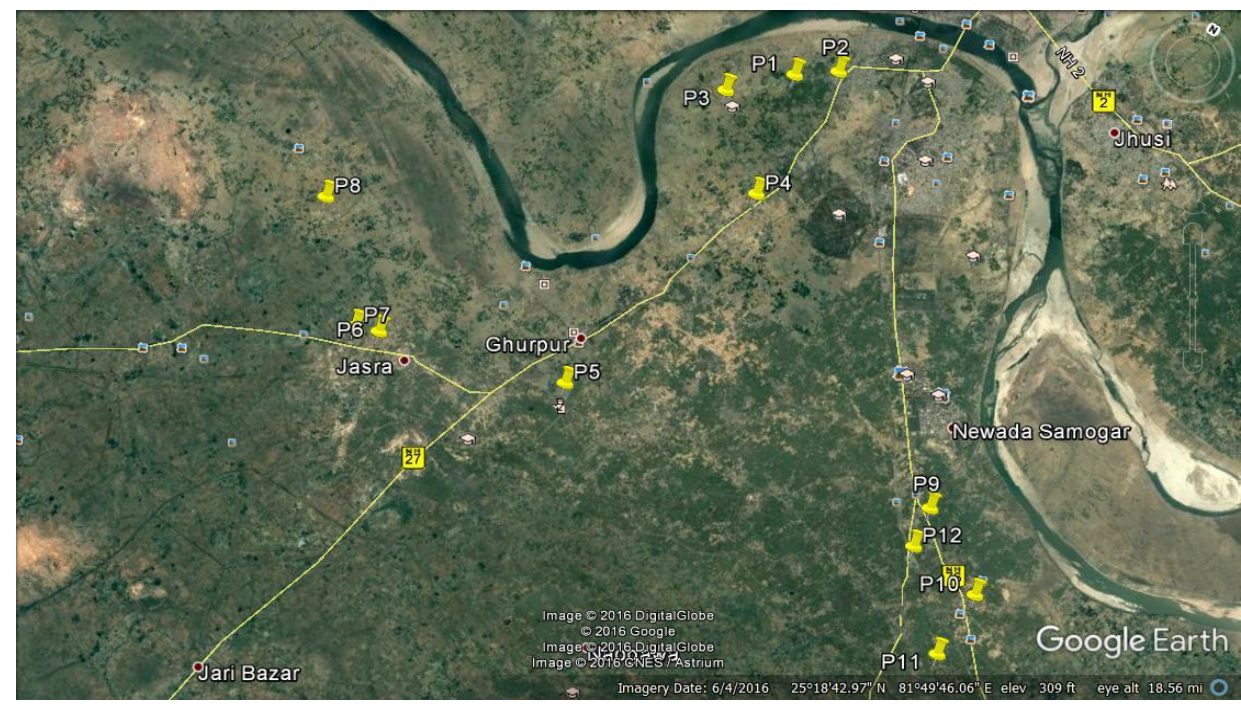


Table.1 Fertility status of the soils of pedons in Jamuna Paar region of Allahabad, (U.P.)

\begin{tabular}{|c|c|c|c|c|c|c|c|c|c|}
\hline \multirow{2}{*}{ Horizon } & \multirow{2}{*}{$\begin{array}{c}\text { Depth } \\
\text { (cm) }\end{array}$} & \multicolumn{4}{|c|}{ Available nutrient $\mathrm{Kg} \mathrm{ha}^{-1}$} & \multicolumn{4}{|c|}{ Available micronutrient $\mathrm{mg} \mathrm{Kg}^{-1}$} \\
\hline & & $\mathbf{N}$ & $\mathbf{P}$ & $\mathbf{K}$ & $\mathbf{S}$ & $\mathbf{F e}$ & $\mathrm{Cu}$ & Mn & Zn \\
\hline \multicolumn{10}{|c|}{ Pedon 1, Block - Chaka, Village -Marauka uparhar: Fine-silty, mixed, active, hyperthermic Typic Ustifluvents } \\
\hline Ap & $0-10$ & 267.00 & 18.12 & 134.92 & 8.45 & 5.83 & 2.91 & 4.46 & 0.76 \\
\hline $\mathrm{Bw}_{1}$ & $10-32$ & 252.00 & 14.21 & 161.21 & 7.53 & 5.62 & 2.76 & 4.43 & 0.65 \\
\hline $\mathrm{Bw}_{2}$ & $32-56$ & 244.56 & 13.16 & 150.22 & 7.28 & 5.61 & 2.45 & 3.91 & 0.52 \\
\hline $\mathrm{Bw}_{3}$ & $56-90$ & 191.26 & 09.26 & 142.01 & 5.21 & 5.45 & 2.12 & 3.56 & 0.42 \\
\hline \multicolumn{10}{|c|}{ Pedon 2, Block - Chaka, Village -Tigonotha: Fine-loamy, mixed, active, hyperthermic Dystric Fluventic Eutrudepts } \\
\hline Ap & $0-12$ & 258.00 & 16.63 & 220.70 & 8.12 & 6.67 & 2.12 & 3.60 & 0.62 \\
\hline $\mathrm{Bt}_{1}$ & $12-35$ & 212.16 & 15.26 & 173.26 & 8.13 & 6.53 & 2.05 & 3.56 & 0.49 \\
\hline $\mathrm{Bt}_{2}$ & $35-78$ & 210.72 & 14.23 & 145.16 & 7.26 & 6.44 & 1.98 & 3.49 & 0.52 \\
\hline $\mathrm{BC}$ & $78-120$ & 198.26 & 11.16 & 161.26 & 6.49 & 6.32 & 1.94 & 2.26 & 0.61 \\
\hline CR & $120^{+}$ & 176.00 & 09.26 & 150.26 & 5.07 & 6.10 & 1.82 & 2.13 & 0.43 \\
\hline \multicolumn{10}{|c|}{ Pedon 3, Block - Chaka, Village - Semera: Fine-silty, mixed, active, hyperthermic Typic Ustipsaments } \\
\hline Ap & $0-13$ & 260.00 & 17.26 & 267.21 & 12.48 & 7.21 & 2.84 & 3.20 & 0.52 \\
\hline $\mathrm{Bw}_{1}$ & $13-36$ & 272.76 & 17.26 & 212.12 & 12.41 & 6.36 & 2.44 & 3.11 & 0.49 \\
\hline $\mathrm{Bw}_{2}$ & $36-70$ & 258.12 & 12.13 & 190.16 & 10.16 & 6.02 & 2.36 & 2.96 & 0.36 \\
\hline $\mathrm{Bw}_{3}$ & $70-100$ & 202.16 & 11.02 & 174.68 & 09.08 & 4.43 & 1.92 & 1.43 & 0.21 \\
\hline \multicolumn{10}{|c|}{ Pedon 4, Block - Chaka, Village -Mohiuddinpur: Fine-loamy, mixed, super-active, hyperthermic Typic Ustifluvents } \\
\hline Ap & $0-20$ & 272.00 & 15.30 & 168.26 & 12.97 & 5.23 & 2.78 & 5.12 & 0.78 \\
\hline $\mathrm{Bw}_{1}$ & $20-38$ & 264.12 & 14.26 & 173.26 & 10.56 & 3.12 & 2.64 & 4.43 & 0.63 \\
\hline $\mathrm{Bw}_{2}$ & $38-80$ & 258.26 & 13.39 & 188.17 & 9.16 & 2.46 & 2.72 & 4.12 & 0.57 \\
\hline $\mathrm{Bw}_{3}$ & 80-115 & 214.19 & 12.16 & 192.16 & 9.12 & 2.48 & 2.46 & 3.43 & 0.43 \\
\hline $\mathrm{Bw}_{4}$ & $115-140$ & 214.93 & 10.00 & 149.20 & 7.56 & 2.43 & 2.12 & 2.96 & 0.39 \\
\hline
\end{tabular}


Continued...

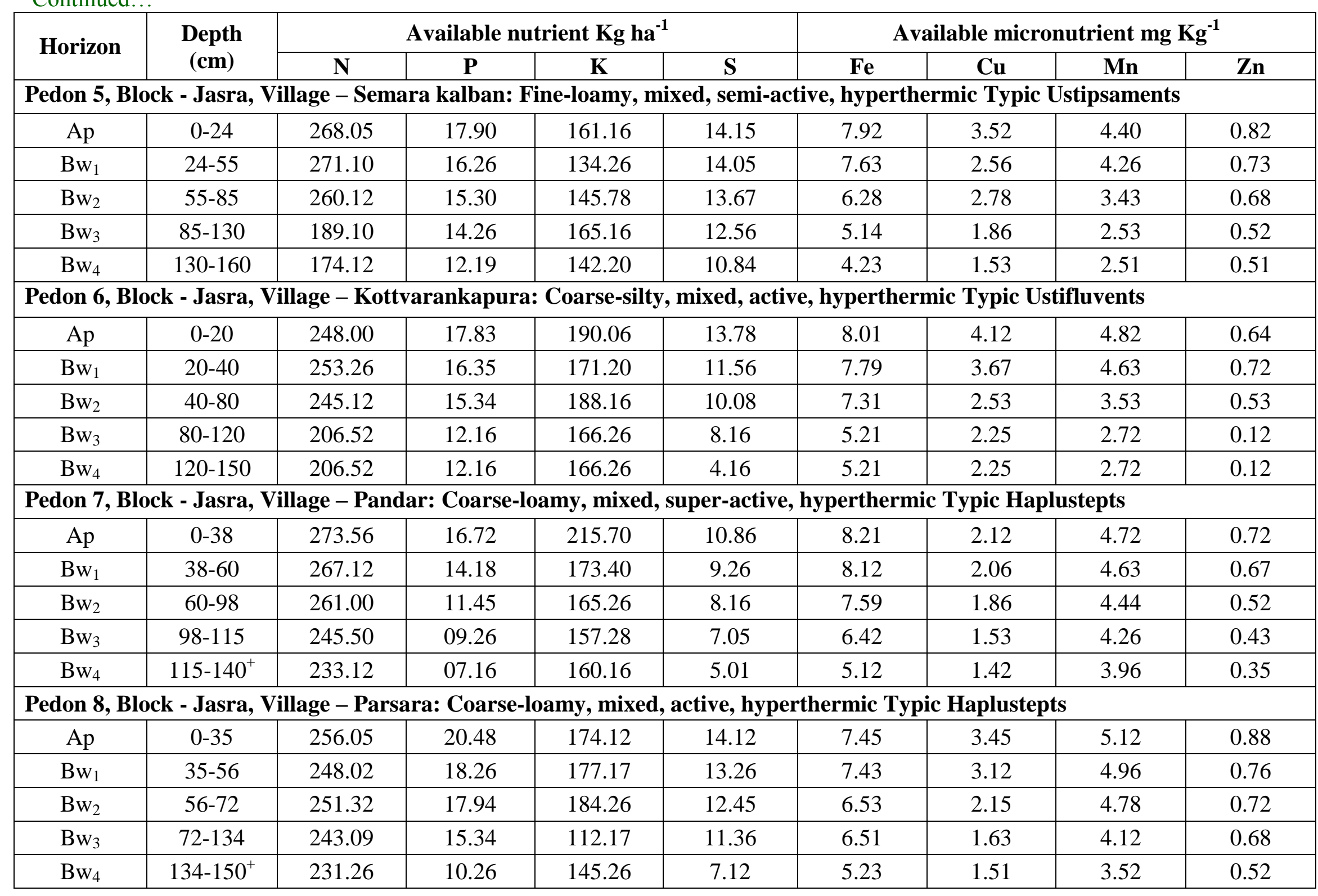


Continued...

\begin{tabular}{|c|c|c|c|c|c|c|c|c|c|}
\hline \multirow{2}{*}{ Horizon } & \multirow{2}{*}{$\begin{array}{c}\text { Depth } \\
\text { (cm) }\end{array}$} & \multicolumn{4}{|c|}{ Available nutrient $\mathrm{Kg} \mathrm{ha}^{-1}$} & \multicolumn{4}{|c|}{ Available micronutrient $\mathrm{mg} \mathrm{Kg}^{-1}$} \\
\hline & & $\mathbf{N}$ & $\mathbf{P}$ & $\mathbf{K}$ & $\mathbf{S}$ & Fe & $\mathbf{C u}$ & Mn & $\mathbf{Z n}$ \\
\hline \multicolumn{10}{|c|}{ Pedon 9, Block - Karchana, Village - Mungori: Fine-silty, mixed, sub-active, hyperthermic Udic Ustifluvents } \\
\hline Ap & $0-18$ & 278.00 & 19.54 & 187.12 & 13.56 & 16.70 & 1.12 & 12.60 & 0.76 \\
\hline $\mathrm{Bw}_{1}$ & $18-40$ & 270.00 & 17.84 & 184.12 & 12.24 & 14.72 & 1.06 & 11.53 & 0.74 \\
\hline $\mathrm{Bw}_{2}$ & $40-68$ & 268.00 & 14.26 & 178.16 & 11.38 & 12.42 & 0.92 & 11.23 & 0.72 \\
\hline $\mathrm{Bw}_{3}$ & $68-96$ & 212.00 & 11.82 & 163.26 & 8.02 & 08.76 & 0.88 & 10.48 & 0.68 \\
\hline $\mathrm{Bw}_{4}$ & $96-120^{+}$ & 215.19 & 11.82 & 165.76 & 7.01 & 05.12 & 0.76 & 10.00 & 0.52 \\
\hline \multicolumn{10}{|c|}{ Pedon 10, Block - Karchana, Village - Bendo: Coarse-silty, mixed, semi-active, hyperthermic Udic Ustifluvents } \\
\hline Ap & $0-18$ & 249.00 & 17.20 & 212.10 & 15.28 & 12.41 & 1.52 & 12.80 & 0.95 \\
\hline $\mathrm{Bw}_{1}$ & $18-44$ & 256.00 & 18.26 & 188.78 & 14.16 & 11.32 & 1.45 & 12.60 & 0.88 \\
\hline $\mathrm{Bw}_{2}$ & $44-96$ & 247.12 & 16.38 & 173.16 & 12.20 & 10.14 & 1.53 & 12.36 & 0.79 \\
\hline $\mathrm{Bw}_{3}$ & 96-135 & 239.09 & 15.30 & 168.82 & 10.26 & 10.08 & 1.36 & 11.44 & 0.61 \\
\hline $\mathrm{Bw}_{4}$ & $135-160^{+}$ & 198.12 & 16.56 & 157.16 & 7.16 & 09.56 & 0.82 & 10.51 & 0.52 \\
\hline \multicolumn{10}{|c|}{ Pedon 11, Block - Karchana, Village - Munglaha: Coarse-silty, mixed, active, hyperthermic Typic Ustipsaments } \\
\hline Ap & $0-14$ & 280.05 & 15.42 & 162.26 & 10.94 & 14.60 & 1.43 & 14.00 & 0.72 \\
\hline $\mathrm{Bw}_{1}$ & $14-26$ & 275.16 & 14.26 & 178.17 & 7.36 & 13.52 & 1.52 & 13.56 & 0.69 \\
\hline $\mathrm{Bw}_{2}$ & $26-55$ & 264.12 & 13.39 & 185.32 & 7.28 & 12.78 & 1.45 & 13.01 & 0.52 \\
\hline $\mathrm{Bw}_{3}$ & $55-94$ & 232.26 & 12.29 & 190.27 & 5.46 & 12.14 & 1.02 & 12.78 & 0.49 \\
\hline $\mathrm{Bw}_{4}$ & 94-150 & 192.08 & 11.16 & 221.45 & 5.68 & 11.46 & 0.92 & 11.53 & 0.21 \\
\hline \multicolumn{10}{|c|}{ Pedon 12, Block - Karchana, Village - Galibabhadh: Coarse-silty, mixed, active, hyperthermic Typic Ustipsaments } \\
\hline Ap & $0-13$ & 265.76 & 16.21 & 148.26 & 10.56 & 13.45 & 1.54 & 15.53 & 0.86 \\
\hline $\mathrm{Bw}_{1}$ & $13-40$ & 251.00 & 15.30 & 154.17 & 10.45 & 12.91 & 1.47 & 14.44 & 0.70 \\
\hline $\mathrm{Bw}_{2}$ & $40-57$ & 246.42 & 12.24 & 163.45 & 10.26 & 12.46 & 1.27 & 14.29 & 0.66 \\
\hline $\mathrm{Bw}_{3}$ & $57-88$ & 234.90 & 11.36 & 155.16 & 10.12 & 11.53 & 0.93 & 13.53 & 0.54 \\
\hline $\mathrm{Bw}_{4}$ & $88-130$ & 217.12 & 10.25 & 170.17 & 8.36 & 10.43 & 0.83 & 12.41 & 0.48 \\
\hline
\end{tabular}


Fig.1 Base map of Jamuna paar region of Allahabad District, (U. P.)

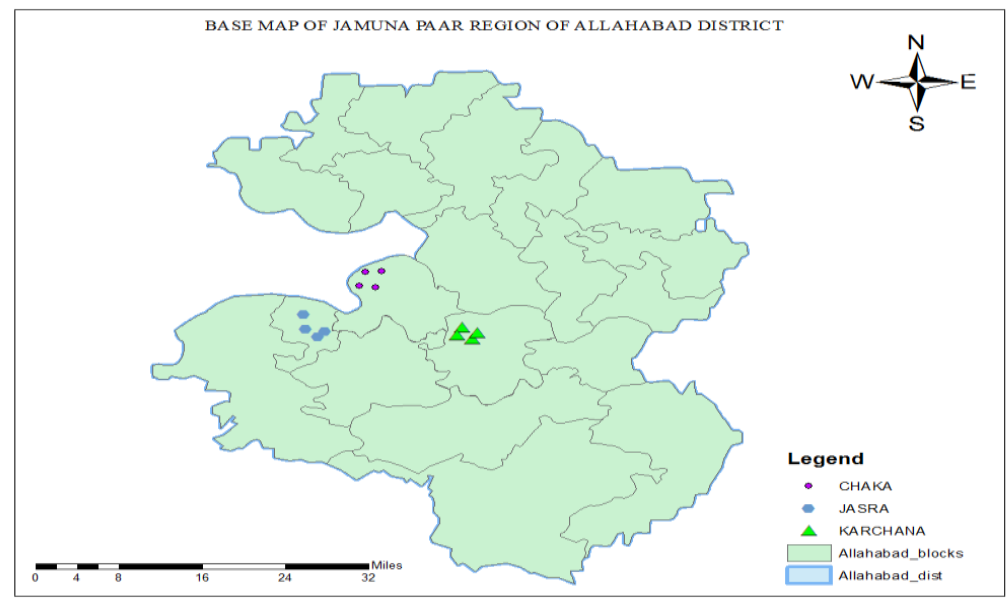

Soils in the study area Jamuna paar region of Allahabad District, Uttar Pradesh. Soils were low in available nitrogen, low to medium in available phosphorus, medium to high in available potassium and low in available sulphur. However, soils were deficient in available zinc and sufficient in available iron, copper and manganese.

The information thus generated in the form of table was used to arrive at meaningful and workable potential land use plan for the Jamuna paar area to bring back the glory of sustainable agriculture. The land resource information system thus generated for the Jamuna paar area can be used as a decision support system to the land users, policy makers and administrators.

\section{Acknowledgement}

I am highly indebted to my advisor for his guidance and constant supervision as well as for providing necessary information regarding the study. I express a heartfelt thanks to The authors are thankful to the Hon'ble Vice Chancellor, HOD and Advisor, Department of Soil Science and Agricultural Chemistry, Sam Higginbottom University of Agriculture, Technology and Sciences, Allahabad, U. P.

\section{References}

Ashok, K.B., (2001). Sulphur status of selected soil series of Karnataka and studies on direct and residual effect of graded level of sulphur on crop. $M$. Sc. (Agri.) Thesis, Univ. Agric. Sci., Dharwad, Karnataka (India).

Black, C.A. (1965). Methods of Soil Analysis.Part I and II. American society of Agronomy. Inc, Madison, Wisconsin, USA.

Brady, N.C. and Weil, R.R. (2004). The Nature and Properties of Soils. 13thedition, Pearson Education (Singapore) Pvt. Ltd., New Delhi, India. Lindsay, W.L. and Norvell, W.A. (1978). Development of a DTPA micronutrients soil test for $\mathrm{Zn}, \mathrm{Fe}, \mathrm{Mn}$ and Cu. Soil Sci. Soc. Am. Proc., 42: 42 1-428.

Patil, S.S., Patil, V.C. and Al-Gaadi, K.A., (2011). Spatial variability in fertility status of surface soils. World Appl. Sci. J., 14(7): 1020-1024.

Rajkumar, G.R., (1994). Studies on forms and distribution of micronutrients in paddy soils of Tungabhadra project area, Karnataka. M. Sc. (Agri.) Thesis Univ. Agric. Sci., Dharwad (India).

Ravikumar, M.A., Patil. P.L. and Dasog, G.S., 
(2009). Soil resource characterization, classification and mapping of 48A distributary of Malaprabha right bank command, Karnataka for land use planning. Karnataka J. Agric. Sci., 22(1):81-88.

Sehgal, J. (1999). Pedology: Concept and Applications. Kalyani publishers. Lodhiana, India.

Singh, K. and Ahuja, R.L. (1990). Distribution of Primary Nutrients in Relation to Soil Characteristics in the Ghaggar River Basin. J. Indian Soc. Soil Sci., 38(4): 733-735.

Subbaiah, B.V. and Asija, G.L. (1965). A rapid procedure for determination of available nitrogen in soil. Curr Sci, 25: 259-260.

Thangasamy, A., Naidu, M.V.S., Ramavatharam, N., and Raghava Reddy, C. (2005). Characterization, classification and evaluation of soil resources in Sivagiri micro-watershed of Chittoor district in Andhra Pradesh for sustainable land use planning. $J$. Indian Soc. Soil Sci, 53(1), 11-21.

Toth, S.J. and Prince, A.L. (1949). Estimation of cation exchange capacity and exchangeable $\mathrm{Ca}, \mathrm{K}$ and $\mathrm{Na}$ content of soil by Flame Photometer Technique. Soil Sci., 67: 439-445.

Vijayasekhar, R., Vittal Kuligod, B., Basavaraj, P.K., Dasog, G.S. and Salimath, S.B., (2000). Studies on micronutrient status in important black soil series of UKP command Karnataka. Andhra Agric. J., 47(1): 141-143.

Watanabe, F.S. and Olsen, S.R. (1965). Test of ascorbic acid method for determining phosphorus in water and $\mathrm{Na} \mathrm{HCO} 3$ extract from soils. Soil Sci. Soc. Am. Proc., 29: 677- 678.

\section{How to cite this article:}

Madhu, B.M. and Arun A. David. 2017. Soil Fertility Status of Jamuna Paar Region of Allahabad District, Uttar Pradesh, India. Int.J.Curr.Microbiol.App.Sci. 6(12): 3069-3076. doi: https://doi.org/10.20546/ijcmas.2017.612.358 